\title{
Misrepresentation of Science and Expertise: Reflecting on Half a Century of Indonesian Anthropology ${ }^{1}$
}

\author{
Irwan Abdullah \\ Universitas Gadjah Mada, Indonesia \\ Email: irwan.fib@ugm.ac.id
}

\begin{abstract}
Indonesian anthropology was founded in 1957 and developed since then in various universities. After more than fifty years of inhabiting these lecture halls, anthropology's orientation as a science has transformed from a discipline that bestows on graduates the ability to think into one in which graduates are prepared for a career of conductingfield research ordered by others. This article reflects on the shifts that have occurred in anthropology, focusing on three of the field's central figures in Indonesia: Koentjaraningrat, Masri Singarimbun, and Parsudi Suparlan. During the lives of these three pioneers, anthropology playeda central role in critically evaluating humanitarian projects, and as such anthropologists frequently served to protect the weak and marginal. Anthropologists were on the frontlines of every discussion regarding the future of the nation, enabling anthropological perspectives to be accommodated in policy. Today, anthropologists seem locked into their own academic spaces. The results of anthropological field research are often said to provide unique and interesting - but irrelevant - stories. This article recommends a fundamental transformation in the curriculum, allowing the politics of science to be reconsidered and reformulated to ensure anthropology maintains a central role in resolving future humanitarian problems.
\end{abstract}

Keywords: Misrepresentation; Anthropologist; Culture; Society; Indonesia

\section{INTRODUCTION}

"We have, it appears, so much to tell each other that we forget to invite others to join the conversation and, similarly, have little time, on our own part, to join theirs."

(Thomas Eriksen)

It is a lengthy story how we got here, to the world known as anthropology. We have obtained diverse benefits from our long journey, from feral peoples, uncivilized peoples, and civilized peoples (Taylor, 1871; Morgan, 1907), from peoples with lives full of magic (Frazer, 1990) and senses of dynamism (Marett, 1914). We have also learned how cultural elements function with societies (Malinowski, 1950), how societies maintain their social structures (Radcliffe-Brown, 1940), how culture configures personality (Mead, 1928; Bennedict, 1934), and how transformations occur over time within society (White, 1943; Steward, 1955). We have also traced the arguments of such thinkers as Sahlins \& Service (196), Sahlins (1972); Harris (1966); and Rappaport (1967). We have also learned from the radical transformations experienced by anthropology after Levi-Strauss showed how the grammar of culture functions to create cultural discourse through the oppositional principle. Levi-Strauss saw culture as a system of classifications rooted within structures of thought (Ortner, 1984). We have followed this system of classification through Needham, Leach, and Douglas, each offering a distinct emphasis. Another radical transformation emerged from the work of Geertz (1973), who argued that culture does 
not exist within the mind (as argued by Goodenough), but is manifested through the symbols that humans use to communicate their views, values, and traditions from generation to generation. Similar views from Schneider and Turner have guided us, though the latter focused more on society than culture (Turner, 1999).

Our journeys as anthropologists have brought us from culture areas (Boas, 1940) to cultural locations (Babbha, 1994), and cultural sites (Olwig \& Hastrup, 1997), thereby creating an awareness of the transforming contexts of anthropological understanding (Stratern, 1995). We have investigated traditions grand and small (Redfiled, 1989), the western and eastern world (Wolf, 1982), with all its disjuncture and difference (Appadurai, 1990). All have taught us how societies live, endure, transform, and die. Brian Bauer's examination of the now-extinct Incan culture (Bauer, 2004), Michael Dove's investigation of the Kantu of Kalimantan (Dove, 1985), as well as research into the Argonauts (Malinowski, 1950), Nuers (EvanPritchard, 1968), Mojokuto in Java (Geertz, 1986a), and more contemporary research into Bali (Hobart, 2000; Vickers, 2012), the Tengger Highlands (Heffner, 1985), and the Gayo of Aceh (Bowen, 1993), have presented us with ethnographical experiences that have informed how anthropologists see reality.

Such studies are not simply academic journeys, but also spiritual ones that guide us towards an awareness of how humans, societies, and cultures are seen, read, understood, and even organized. All human stories and suffering influence how we see the worldunited by the forces of information and communication, be it from the perspective of Marxist historical particularism (Marx and Engels), cultural materialism (Harris), structural symbolism (Levi-Strauss), functionalism (Malinowski), structural functionalism (Radcliffe-Brown), as well as hermeneutics or symbolic anthropology (Geertz) and anthropology of practice (Bourdieu) or the anthropocene(Latour).

Necessary (and unnecessary) contrastshave been found in diverse settings, helping us understand what has happened and is happening in the past and the present. This has become particularly prominent in the contemporary era of postmodernism (Rabinow, 1984), with its unceasingly expanding borders (Appadurai, 1996), and linking humanity in a transnational community (Hannerz, 1996). We face a world that has become increasingly open (Friedman, 1994; Eriksen, 2014), negating our awareness of the validity of space and time.
Although anthropologists have become increasingly needed as ethnographersable to impartothers with "wisdom", we havelost the intelligence and diction for suggestion, and even the very backbone that enables us to address suffering. When the "wisdom" of Indonesia's culture is questioned, we no longer see any steps towards defending it or bringing enlightenment. Anthropologists, as stated by Erikson, must have the ability to contribute intellectually to discussions of humanity, rather than ourselves (Erikson, 2007).

This article is an evaluative one, examining the state of anthropology today, particularly the tendencies in academic and non-academic life in Indonesia. What has been lost, and what can be expected of anthropology in the future? It positions anthropology at the center of discussion, which can be referenced to better understand society and social orders.

\section{THE DEVELOPMENT OF ANTHROPOLOGY: PAST AND PRESENT}

After visiting so many places and conducting field research with so many different perspectives, approaches, and methods, where are we now? Has there been greater recognition of anthropology? Have anthropologists received an appropriate position in the social order and in social transformation?In this plural society, with its multiple ethnicities and high degree of cultural diversity, anthropology cannot simply be pushed aside or ignored. Anthropologists should rise to the surface, take a central role in discourses about and practices of humanity, culture, and society. We require anthropologists and anthropology graduates who are not only capable of recovering beautiful jewelry from the sea floor, but also capable of telling stories using readily understood language and offering solutions for human problems.

We must, at the very least, bring greater prestige to anthropology, make it the "queen of the social sciences" (Benthall, 2002), a central or core science rather than one that solely supports other sciences (Erikson, 2007). With good methodology and epistemology, anthropology should become a high profile discipline, capable of using detailed and comparative research to respond to core intellectual questions as well as broader questions of humanity. The present situation is far from that expected by the founders of anthropology.

In 1989, when Raymond Firth was asked to 
attend the 25th anniversary of the Anthropology Department at the University of Oslo, he expressed great concern for the increasingly closed nature of anthropology and anthropologists. At the time, Firth (1989)urged anthropologists to adapt to new world contexts, especially the rise of computers and biotechnology.Almost ten years later, Keith Hart asked - in response to the lack of appreciation for anthropology as a profession and science - that we partake in what he termed the "long conversation of anthropology".

Three things, I argue, are crucial for anthropology. First, anthropology has tended to focus solely on small-scale societies, those that are unique, isolated from the outside world, and firmly delineated. Citing baseless fears, we even protect them from outside influences. Anthropologists have become, according to Mary Douglas in Purity and Danger, afraid of impurity and outside contamination, and as such attempt to protect these societies from the "threat" of outside influences and values (Douglas, 2002). We still rely on conceptual cultural boundaries and experience anthropological objects as closed spaces, fixed and unchanging even as the spaces and times around them change and (re)define social identities (Abdullah, 2006).

It appears that we blame isolation on smallscale societies, delineate them as border communities, indigenous peoples, island societies, or even urban communities, and then seek to "purify" them of various influences. It is not uncommon for us to fight for their "salvation" without asking for their opinions. Where is our anthropological awareness? In one cartoon, Gary Larson depicted a tribe of Native Americans hiding their radios and tape recorders, televisions, and computers when seeing two foreigners approaching themas the warning of "Anthropologists! Anthropologists!" rang out. In this cartoon, the Native American tribe acts as though it perceives that the anthropologists neither expect nor desire any change in the community they are studying, and that these foreigners are unwilling to accept that the Native tribe is no longer "primitive". Similar concerns were voiced by none other than Vine Doleria, who argued that anthropologists frequently take the (self-)definition rights of indigenous peoples for themselves (Deloria, 1969).

Second, we have a tendency to speak solely among ourselves and neglect to ask to hear the stories of people from other disciplines. Likewise, when people from other disciplines tell their stories, we rarely make the time to come and listen to them. As Eriksen (2007) writes,"we have, it appears, so much to tell each other that we forget to invite others to join the conversation and, similarly, have little time, on our own part, to join theirs."Eriksen emphasizes the lack of interaction between anthropologists and other social scientists, as a result of which the unique concepts and characteristics developed within anthropological transitions cannot enrich or benefit other disciplines. Our frequent use of terms that differ from those used by other disciplines further limits interdisciplinary communication.

In anthropology, we rarely practice what Marcell Mauss calls "giving, receiving, and returning the gift" (Mauss, 2000). The exchange of knowledge is limited, creating what Geertz (1983)identifies as an "involution"in academia. We are not sufficiently open to others' views, and as a result we are often considered too "afraid" of becoming contaminated by the thoughts and concepts of others. Why is such purification important, and why must we protect our conceptual frameworks from views outside our control?"Wild" ideas cannot easily develop, let alone be used to understand society in general.

When anthropologists create surprising comparisons and contrasts, they are often trapped by tendencies that isolate them from broader society. Eriksen (2007), for example, argues that the stories of economists are "important", of sociologists are "useful", and of anthropologists are "interesting". In other words, the stories of anthropologists may bring awe or laughter to others, or be considered irrelevant. Keith Hart even wrote that anthropology lessons are irrelevant outside the classroom (Hart, 1974). Anthropologists' challenge is to relaytheir findings not to draw laughter, or exhibit naivety, but a clever and wise "alternative means" of understanding the world and how it is ordered.

Third, the characteristics of our science and ethnographies are acontextual.We tend to limit ourselves not only in terms of scale, to small-scale societies, groups, tribes, and communities, but also in terms of scope, focusing on issues of magic, rituals, and symbols that are viewed as wholes without consideration of the macro or universal framework in which they are situated. This tendency is apparent in anthropology becoming increasingly ideographical as nomothetic perspectives are increasingly abandoned. It is not surprising that anthropology has failed to find what may be termed the "natural law of society". Anthropology cannot always consider small- 
scale communities, because these communities experience continued transformation and are shaped in part by outside forces. Transformations in these communities affect not only the composition of society, but also members' responses to changes outside their villages and communities, as well as the bonds and boundaries that affect them. At the same time, the state and market has eroded the traditional communalist ideology. Different outside values have been spread through policies and regulations that demand community members' deference. Likewise, global forces are spread through various ideas, values, practices, and products, which not only require adaptation but also create new frameworks and measures within society. These transformations, both internal and external, require an anthropological perspective as well as contextual anthropological solutions.

To evaluate these developments and understand their direction, three Indonesian cultural anthropologists may be referenced, focusing on the shape of anthropology in their hands. Although these three cultural anthropologists have died, their thoughts and spirits still live with us in the realm of Indonesian anthropology.

\section{THREE ANTHROPOLOGISTS: CONTEMPLATING LOST THINKERS}

After more than half a century of Indonesian anthropology, three names rise to the forefront: Koentjaraningrat, Masri Singarimbun, and Parsudi Suparlan (Figure 1). PakKoen, Pak Masri, and Pak Parsudi (as they were often called) not only gained reputations in academia through their influential publications, but also their involvement in policymaking by "honing the eyes of policy makers" and helping them see the dark side of development, and shifting its orientation towards humanity and human development. They became "walking dictionaries" for understanding humans, humanity, and culture in this complex country. They also promoted greater awareness of anthropology and its influence on Indonesia's social, economic, and political spheres.

Pak Koen was the founder of Indonesian anthropology and worked to educate students who later became anthropology teachers and professors at universities throughout Indonesia. His international experiences as a student and professor strongly influenced him and the character of the anthropology he taught. His reception outside of academia, particularly in the government and military, indicates the wide acceptance of anthropology. Pak Koen eventuallywrote Kebudayaan, Mentalitas, dan Pembangunan ("Culture, Mentality, and Development", 2000) to imparthis concernfor development, as examined from an anthropological perspective. Through his diverse writings, Pak Koen fought for human and cultural dimensions to be included in development programs. Ultimately, in Indonesia, the name Koentjaraningrat became identified with anthropology itself.

Figure 1.

Koentjaraningrat, Masri Singarimbun, and Parsudi Suparlan (left to right)
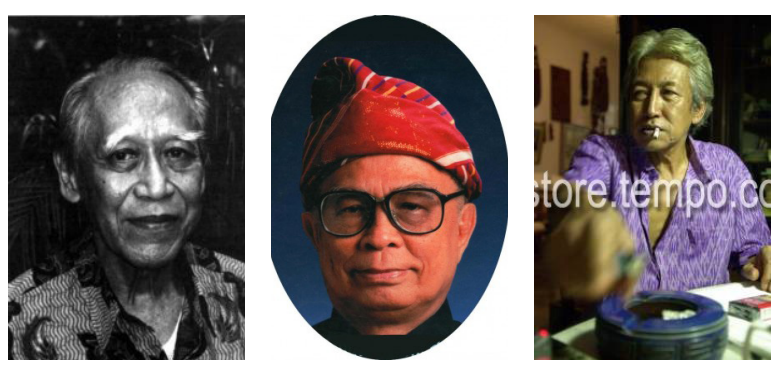

Pak Koen's views were highly transformative. Aside from promoting the establishment of anthropological departments in various universities, he also presented clear ideas for guiding Indonesia's development. He argued that the people of Indonesia needed to be transformed to eliminate those characteristics that were not conducive to progress and develop other necessary characteristics, such as confidence, discipline, and responsibility (Koentjaraningrat, 2000). His writings showed how Indonesia's culture, in all its diversity, could be understood, arguing that progress would be realized more readily with a greater understanding of Indonesia's people and culture. For this, Pak Koen believed it necessary to utilize anthropology as part of social transformation, and that such involvement was the duty of every anthropologist (Koentjaraningrat, 1984).

The second anthropologist discussed here, Pak Masri, was a serious researcher who began to collect a thousand Batak Karo proverbs. Aside from writing research reports, Pak Masri frequently wrote columns in popular print media such as Tempo.His columns, casual and at times funny, were often awaited by readers and inspired many (Singarimbun, 1992). After returning from studying (and teaching) in Australia, Pak Masriestablished the Center for 
Population Studies (which has been renamed several times and is now known as the Center for Population and Policy Studies of UGM) and became a nationally known intellectual. On the issues of population and family planning, PakMasri was second to none, and the results of his research shaped the government's population policies in spite of his sometimes controversialviews. Pak Masri fought fearlessly for truth and honesty in field data, as shown in his study onpoverty in Sriharjo (1977), which changed the direction of government policies regarding poverty and population. PakMasri also sought to protect the human rights of transmigrants and condemned their troubling and at times inhumane treatment (Swasono \& Singarimbun, 1986).

Pak Masri's academic approach has two key points. First, he was critical of a range of policies that he considered incompatible with the ideals of development. This was not limited to transmigration, family planning, and poverty eradication, but also migrant labor, healthcare, education, and various aspects of bad governance. Second, he sought transformation and progress for the Indonesian people. Pak Masri incessantly pushed for progress and urged his students to adopt a transformative attitude, change social situations, and guide communities as they seek self-determination. Pak Masri frequently went to the field to directly observe phenomena being experienced by communities and to push them to determine their own fates. In his writings, it is apparent that he considered the common people, as well as the most insignificant of phenomena and problems, to be related to or even resulting from larger processes that must be handled with skill (Singarimbun, 1992).

Pak Parsudi, as with Pak Koen and Pak Masri, presented a new perspective through his research (1995), particularly by distancing himself from conventional studies. His investigations of the Javanese of Suriname heralded a new chapter of Indonesian anthropology, particularly as related to social and cultural transformations (see Stratern, 1995). Likewise, his studies of ethnicity heavily influenced Indonesian policymaking. Pak Parsudi examined urban areas, poverty, and various relevant aspects of culture (Suparlan, 1984). Pak Parsudi also promoted a greater awareness of the importance of anthropology, particularly among the military, through the examination of non-military means of security and law enforcement.Pak Parsudi wrote numerous works, and earned the reputation of an honored and respected anthropologist.
His critical attitude, both towards his readings and ongoing phenomena and situations, colored his appearances in a number of forums. Pak Parsudi showed how scientists could analyze various phenomena in detail and identify the diverse issues emerging in society. Various groups' acceptance of anthropology as a scientific discipline highlights how Pak Parsudi positioned anthropology as providing a necessary perspective for understanding the dynamic developments being experienced in Indonesia, as seen inhis views of multiculturalism and conflict in the country (Suparlan, 1999). In one of this writings, regarding conflict resolution efforts by the police, Pak Parsudi critically underscored how many police officers had neglected their duty to prevent or resolve conflict, which he considered a result of institutional desynchronization caused by a lack of clarity in the division of authority between the police and military (1999: 17).

Today, even though these three anthropologists have passed away, their academic prowess and teachings should be contemplatedas we map out the current and future shape of Indonesian anthropology. They were of a generation of hard workers, intellectual ascetics who sought to create quality academic works based on diligent field research and presented in various academic and practical forums, as well as to use their research to promote broader humanitarian interests. The three gaveus three points for contemplation.

First, anthropologists have been involved in lengthy debate on humanitarian issues, and have historically had space to become involved in social development and apply their knowledge and understandings about humanity and culture around the world. They did not speak only about anthropology, but also about humanitarian problems that required the attention and concern of various groups and parties. The three men were important thinkers who became actively involved in academic and practical discussions and debates. They sought to become involved in the addressing of every problem faced by the country, and their anthropological discipline allowed them to provide answers that became increasingly refined over time.

Second, these anthropologists were strong and firm in maintaining the integrity of their research. When explaining the results of their research, they were uncompromising and unwilling to be controlled, at times even going against those in power in the name of the greater good. They worked out of an academic 
desire for intellectual asceticism and produced works that could serve as a material or tool for defending the truth and creating commitment tohuman development Under their example, the role of the researcher shifted from that of an academic in an ivory tower toa promoter of human development, where necessary.

Third, all three were committed to academic quality and worked hard not only to promote the quality of individual researchers, but also the quality of institutions under their leadership. They conceptualized anthropologists as working towards transformative goals that sought to promote greater fairness and openness in society. With the quality of their research, they sought to change the fates of others and of anthropology itself.Anthropology gained a reputation for inspiring alternative means of promoting prosperity and human development.

After the death of these three researchers, what does the future hold for anthropology?

\section{PROBLEMATIC HABITS IN ANTHROPOLOGY}

Many thoughts and practices have become habitual, despite being problematic. The processes through which anthropologists work require integrative relations to produce graduates with the expected qualities. As such, from the beginning of their educations, students must be integrated into a system that promotes certain quality standards among graduates. In the learning process, there are three key aspects that I believe we must consider re-examining.

First, there is a mistaken tendency in the research conceptualization and discourse positioned as the end product of the anthropology learning process. Research is seen as the peak of academic prestige, even though - as shown by the three pioneers discussed above - anthropologists are "thinkers" (not simply researchers) involved in lengthy debates about humanitarian issues. The thoughts and views of anthropologists must become the basis for creating a better world. Research must be used as a tool for creating greater wisdom and intelligence among anthropologists, consequentlyenabling them to become involved in society. When anthropologists are involved in research projects, they are often unproductive as they lack authority over data and research findings. As a result, they are unable to produce relevant views that promote humanitarian interests and human development.

Anthropologists have been reduced to "mere researchers" by obscuring their other roles and narrowing the definitions of anthropology itself.
Anthropologists should play advocacy roles, and use data to promote humanitarian goals.It is dangerous when the works of anthropologists are translated by political and financial authorities, with anthropologists positioned as doing nothing but providing resources to promote their authority. The idea of a "paid researcher", which has become prominent over the past few decades, has ultimately limited the ability of anthropology students to become "thinkers" promoting human development. Anthropologists must play a number of noble and grand roles, not simply becomingresearchers. As noted by Keith Hart (1974), anthropologists are part of a lengthy discourse.

Second, there is the view that limits anthropology to the study of "unique" characteristics of small-scale societies. Societies are seen as isolated entities, rather than as part of a historical continuum with logical similarities: how these "isolated entities" resolve conflict could become the basis of conflict resolution strategies in modern societies. What occurs within adat communities must be recognized as part of broader networks of knowledge and civilization. What Eriksen (2001)terms "small places, large issues"must be considered an anthropological inevitability, with long-term research into "small places" or societies seeking to understand said small places in relation to relevant and broader issues. Small truths must also be seen in relation to larger ones. They may serve as the basis for or develop into larger truths (Wertheim, 1964), contribute to the presence of such truths (Wolf, 1982), or become part of a system (Wallerstein, 2001). As such, local wisdom may serve as the basis for broader understandings and orderings.

Anthropological research has made significant contributions to broader social processes. MargaretMead, for example, contributed to discourse onbroader social transformations, not only about puberty among adolescents (Mead, 1928).Boas (1940) and Malinowski (1950), as with other later anthropologists (i.e. Comaroff \&Comaroff, 2009) made highly relevant contributions to understanding contemporary issues. Evans-Pritchard even stated that his examination of the magical practices of the Zande shed light on political processes in the Soviet Union (see Evans-Pritchard, 1976).As such, anthropological research must consciously position research subjects within an integrated framework that considers both space and time contexts.

Third, there is a problematic tendency to view culture as a "material object", thereby limiting anthropologists' movement and concealing their 
abilities. We produce works that are relatively irrelevant because they focus too much on culture as a material object, rather than a paradigmatic formal object. Culture is nothing less than a paradigm that gives anthropologists their identities and enables them to better contribute to understanding humanity (Abdullah, 2006).In line with this, Hastrup argues that we must define humanity as an epistemology, rather than an object (Hastrup, 1995). As such, culture is not an object, but rather a perspective for understanding the human situation and human problems.

Culture, as a perspective, will make it possible for anthropology to become a discipline that records, reads, and understands various phenomena through a cultural perspective. A cultural perspective will, first, make it possible for anthropology to offer an alternative understanding to that of the relatively mature social, economic, and political perspectives. The cosmology, values, and norms of society, as well as social institutions,traditional practices, and material culture will offer an understanding of humans' existence within dynamic and interconnected societies. Second, a cultural perspective will ease anthropologists in contributing to the resolution of various social, political, economic, and religious issues. Anthropologists' contributions can hone the understanding of the broad issues that develop in society.

Fourth, it is a mistake to consider anthropology as the study of culture, as this would overlap with cultural studies. Unlike anthropology, cultural studies examines the contemporary dynamics of culture and how cultural practices are linked to powersystems. In cultural studies, social phenomena such as gender, ethnicity, generation, class, and identity cannot be separated from how they operate within the system ofpower (Hall, 1980; During, 2005). Anthropology, meanwhile, is more "the study of man" (Linton, 1964), and thus applies a cultural perspective to the study of humanity. It can thus be understood that humans can also be researched from a biological, medical, or political/economic perspective.

The cultural anthropology approach considers culture a means of understanding humans, their thoughts, their values, their desired/undesired behaviors, and their products. Some emphasize time, arguing that anthropology examines humans in the past and present (i.e. evolution), but generally anthropology is linked to behavior within certain environments (i.e. adaptation). In other words, anthropology considers societies in their early, traditional, and modern forms throughout the world. In various areas, it is taught that variety exists within all human cultures, and cultural transformation occurs together with historical change.

Noting how anthropology tends to be defined and taught today, anthropology education must be reoriented to center on humans, including their language, social organization, livelihoods, knowledge, art, technology, and beliefs, all of which can be seen as means through which humans present and maintain their humanity in different spaces and time.

\section{CONCLUSION: TOWARDS THE FUTURE OF ANTHROPOLOGY}

Even as anthropological concepts have been borrowed by other disciplines, they remain debated amonganthropologists. We have yet to create a shared understanding of how to understand and see culture. Even as anthropologists continue their debates, their concepts have long been used to introduce new ideas and practices to the world of medicine (Singer, 1995). Meanwhile, anthropology has been used to ease development programs that have ironically been detrimental to people and their cultures (Chambers, 1985). Many companies, hiring anthropologists to ensure the quality of their products, have positioned people as nothing but objects (Jordan, 2010). How, then, can human interests be defended or human sovereignty be maintained? Three considerations may lay the foundation for action plans that allow anthropologists to position their discipline more openly and dynamically.

First, anthropologists must promote the transformative abilities of their discipline to ensure that they do not objectify people or cultures.Human beings must not be reduced to mere objects, particularly by those who claim to study humanity. Subjectification is necessary, and particularly urgent given the increasing openness and democracy of the modern world. In this context, anthropology must work to promote a transformation in the paradigms of academia and practice. The concept of "transferringknowledge"must become "sharing knowledge"to ensure that local wisdom (culture) is present in and contributes to improving social systems. Thus far, local wisdom has not had space in the production of knowledge, and the potential of those in the margins is ignored. Anthropologists have the ability to create and promote this space in diverse narratives, thereby ensuring that knowledge production is not a monolithic endeavor.

Second, honing the epistemology of humanity is necessary to transform how people are viewed 
as objects of study. Culture is not an object, but a perspective used to understand human problems and concerns. As noted by Malinowski, we cannot study human problems without humans. Researchers, such as university students in Scandinavia, have examined identity politics among Indians, unemployment in suburban Oslo, second-generation Turkish migrants and their transnational linkages, Maghrebi youths in Paris, the "dot com" hype in Sweden, rather than focusing on migration, rituals, and magic. Where studies of magic are undertaken, they have seen their object as reactions to the neocolonial and neoliberal policies of the World Bank.The expansion of anthropological perspectives have offered graduates greater opportunity to apply their critical views in their promotion and upholding of the truth.

Third, we must reinforce our protection of the marginalized.Initially, anthropologists' views were co-opted by national ideologies, and thus anthropologists were often seen as defenders of the state. Using the wisdom of anthropologists, the state became increasingly powerful. As the world became increasingly influenced by the market, anthropologists became co-opted by private sector interests that sought to maximize their profits. In such situations of co-option, who remains to defend those marginalized by the state and by capitalist forces? The expertise of anthropologists must not be commoditized, or the unique characteristics and abilities of the discipline used to oppress others or repeat the imperialism of the past. Activism must become an inseparable part of anthropology, and anthropologists must protect humanitarian values in this world that is increasingly narrated by those in power.

We require a clear theoretical position as well as a firm moral position. Every day we become more ideographical, less nomothetic, and our theoretical position becomes increasingly unclear and limits our contributions to conceptual debates. Major steps need to be taken to ensure that anthropologists avoid becoming "people interested solely in themselves and their findings, who develop their thoughts and views uniquely and individually, thus becoming irrelevant to real life." And we thus lack the capacity to protect or support anyone.

\section{ENDNOTE}

1) I owe a great debt to Clifford Geertz and Thomas Hylland Eriksen for their conceptual understandings of the future of anthropological theory and practice, as well as Frans Husken for our many discussions, which remained incomplete until we last parted at his funeral in Westerveld, the Netherlands.

\section{REFERENCES}

Abdullah, I. (2006). Konstruksi dan Reproduksi Kebudayaan. Yogyakarta: Pustaka Pelajar.

Appadurai, A. (1990). Disjuncture and Difference in the Global Economy. Pennsylvania: University of Pennsylvania.

Appadurai, A. (1996). Modernity at Large: Cultural Dimensions of Globalization. Minneapolis \& London: University of Minnesota Press.

Asad, T. (Ed.). (1973). Anthropology and the Colonial Encounter. London: Ithaca Press.

Bhabha, H. (1994). The Location of Culture. London and New York: Routledge.

Benthall, J. (2002). Introduction In Jonathan Benthall (Ed.), The Best of Anthropology Today (pp. 1-15). London: Routledge.

Boas, F. (1940). Race, Language, and Culture. Chicago: The University of Chicago Press.

Bauer, B.S. (2004). Ancient Cusco: Heartland of the Inca. Austin: The University of Texas Press.

Benedict, R. (1934). Patterns of Culture. New York: Houghton Mifflin.

Bowen, J. (1993). Muslims through Discourse: Religion and Ritual in Gayo Society. Princeton: Princeton University Press.

Chambers, E. (1985). Applied Anthropology: A Practical Guide. New York: Prentice Hall.

Comaroff, J.L.,\&Comaroff, J. (2009). Ethnicity, Inc. Chicago: The University of Chicago Press.

Deloria, V. (1969.) Custer Died for your Sins: An Indian Manifesto. New York: Macmillan.

Douglas, M. (2002). Purity and Danger. London: Routledge.

Dove, M.R. (1985). Swidden Agriculture in Indonesia: The Subsistence Strategies of the Kalimantan Kantu'. Berlin: Mouton Publishers.

During, S. 2005. Cultural Studies: A Critical Introduction. London \& New York: Routledge.

Eriksen, T. (2001). Small Places, Large Issues: An Introduction to Social and Cultural Anthropology. London: Pluto Press.

Eriksen, T. (2007). Perilous Identity Politics, the Loss of the Primitive and an Anthropology that Matters: Some Reflections about Anthropology in the New Century.In Vassilis Nitsiakos et al. (Eds.), Balkan 
Border Crossings: second Annual of the Konitsa Summer School. Zurich: LIT Verlag GmbH \& Co. Eriksen, T. (2014). Globalization: Key Concepts. London: Bloomsbury Publishing.

Evans-Pritchard, E.E. (1968). The Nuer. Oxford: Oxford University Press.

Evans-Pritchard, E.E. (1976). Witchcraft, Oracles and Magic among the Azande. Oxford: Clarendon Press.

Firth, R. (1989). The future of social anthropology. Lecture given at the Department of Social Anthropology, University of Oslo, 1989.

Frazer, J.G. (1990). The Golden Bough. New York: Palgrave MacMillan Press.

Friedman, J. (1994). Cultural identity and Global Process. London: Sage Publications.

Geertz, C. (1973). The Interpretation of Cultures. New York: Basic Books.

Geertz, C.(1983). Involusi Pertanian: Proses Perubahan Ekologi di Indonesia. Jakarta: Bhratara Aksara.

Geertz, C. (1986). Mojokuto: Dinamika Sebuah Kota di Jawa. Jakarta: Pustaka.

Goody, J. (1995).The Expansive Moment: Anthropology in Britain and Africa 1918-1970. Cambridge: Cambridge University Press.

Hall, S. (1980). Cultural Studies: two Paradigms. London: Academic Press, Inc.

Hannerz, U. (1996). Transnational Connections: Culture, People, Places. London \& New York: Routledge.

Harris, M. (1966). The Cultural Ecology of India's Sacred Cattle. Current Anthropology, Vol. 7, No. 1, pp. 51-64.

Hart, K. (1974). Anthropology and the colonial encounter (book review). British Journal of Sociology, 1974, pp. 265-266.

Hart, K.(1998). The place of the 1989 Cambridge Anthropologial Expedition to the Torres Straits in the history of British social anthropology. Conference paper presented at Anthropology and Psychology: The Legacy of the Torres Straits Expedition, University of Cambridge 10-12 August 1998.

Hastrup, K. (1995). A Passage to Anthropology: Between Experience and Theory. London: Routledghe.

Hastrup, K.(2005). Social anthropology: Towards a pragmatic enlightenment? Social Anthropology, vol.. 13, pp. 133-149.

Heffner, R.W. (1985). Hindu Javanese: Tengger Tradition and Islam. Princeton: Princeton University Press.

Hobart, M. (2000). After Culture: Anthropology as Radical Metaphysical critique. Denpasar: Program Studi Magister Kajian Budaya UNUD.

Jordan, A.T. (2010). The Importance of Business Anthropology: Its Unique Contributions.
International Journal of Business Anthropology, Vol. 1, No. 1, pp. 15-25.

Kearney, M. (2004). Changing Fields of Anthropology: From Local to Global. Oxford: Rowman \& Litttlefield.

Knauft, B. (2006). Anthropology in the middle. Anthropological Theory, Vol. 6, pp. 407-430.

Koentjaraningrat (1983). Kebudayaan, Mentalitas dan Pembangunan. Jakarta: Gramedia.

Koentjaraningrat (1984). Masalah-masalah Pembangunan: bunga Rampai Antropologi Terapan. Jakarta: LP3ES.

Linton, R. (1964). The Study of Man. New York: Appleton Century Crofts.

Malinowski, B. (1950). Argonauts of the Western Pacific: An Account of Native Enterprise and Adventure in the Archipelagoes of Malanesian New Guinea. London: Routlege \& Kegan Paul.

Marett, R.R. (1914). The Threshold of Religion. New York: The MacMillan Company.

Mead, M. (1928). Coming of Age in Samoa: A Psychological Study of Western Youth for Western Civilisation. New York: William Marrow \& Company.

Mauss, M. (2002). The Gift: The Form and reason for Exchange in Archaic Societies. London \& New York: Routledge.

Morgan, L.H. (1907). Ancient Society or Researches in the Lines of Human Progress from Savagery through Barbarism to Civilization. New York: Henry Holt \& Company.

Olwig, K.F., \&Hastrup, K. (1997). Siting Culture: The Shifting Anthropological Object. London and New York: Routledge.

Ortner, S.B. (1984). Theory in Anthropology Since the Sixties. Comparative Studies in Society and History, Vol. 26, No. 1, pp. 126-166.

Rabinow, P. (1984). The Foucault Reader. London: Penguin.

Radcliffe-Brown, A.R. (1940). On Social Structure. The Journal of the Royal Anthropological Institute of Great Britain and Ireland, Vol. 70, No. 1, pp. 1-12.

Rappaport, R.A. (1967). Pigs for the Ancestors. New Heaven: yale University Press.

Redfield, R. (1989). The Little Community and Peasant Society and Culture. Chicago: The University of Chicago Press.

Sahlins, M. (1972). Stone Age Economics. Chicago: Aldine.

Sahlins, M. \& Service, E.R. (1960). Evolution and Culture. Ann Arbor: University of Michigan Press.

Singarimbun, M. \& Penny, D.H. (1973). Population 
and Poverty in Rural Java. Some Economic Arithmetic from Sriharjo. Ithaca: Department of Agriculural Economics.

Singer, M. (1995). Beyond the Ivory Tower: Critical Praxis in Medical anthropology. Medical Anthropology Quarterly, Vol. 9, No. 1, pp. 80-106.

Steward, J. 1955). Theory of Culture Change. Urbana: University of Illinois Press.

Strathern, M. (1995). Shifting Contexts: Transformations in Anthropological knowledge. London: Routledge.

Suparlan, P. (1984). Kemiskinan di Perkotaan: Bacaan untuk Antropologi Perkotaan. Jakarta: Sinar Harapan.

Suparlan, P. (1995). The Javanese in Suriname: Ethnicity in an Ethnically Plural Society. Arizone: Arizona State University Press.

Suparlan, P. (1999). Konflik Sosial dan Alternative Pemecahannya. Antropologi Indonesia, Vol. 59, pp. 7-19.
Swasono, S.E.,\&Singarimbun, M. (1986). Transmigrasi di Indonesia, 1905-1985. Jakarta: Penerbit Universitas Indonesia.

Taylor, E.B. (1971). Primitive Culture: Researches into the Development of Mythology, Philosophy, Religion, Art, and Custom. London: John Murray.

Turner, V. (1999). The Ritual Process: Structure and Anti-Structure. Oxon: Routledge.

Vickers, A. (2012). Bali: A Paradise Created. North Clarencon: Tuttle Publishing.

Wertheim, W. (1964). East-West Parallels. The Hague: Van Hoeve.

White, L.A. (1943). Energy and the Evolution of Culture. American Anthropologist, Vol. 45, No. 3, pp. 33556.

Wolf, E. (1982). Europe and the People Without History. Berkeley: University of California Press. 